\title{
Prerequisites of Improving Professional Training of Social Workers
}

\author{
Olga Sokolova \\ Department of theory and \\ history of social pedagogy and \\ social work \\ Orel State University \\ Orel, Russia \\ ov_filatova@mail.ru
}

\author{
Elena Filatova \\ Institute of Social Sciences and \\ Psychology \\ Kemerovo State University \\ Kemerovo, Russia \\ filatova.fev@yandex.ru
}

\author{
Irina Rodina \\ Department of theory and \\ history of social pedagogy and \\ social work \\ Orel State University \\ Orel, Russia \\ iv_proshkina@mail.ru
}

\author{
Nataljya Shmireva \\ Institute of Education \\ Kemerovo State University \\ Kemerovo, Russia \\ n.shmireva@yandex.ru
}

\begin{abstract}
The relevance of the study is caused by the need to improve the theoretical and practical training of social workers. In the process of global changes of modern society, the social problems have become aggravated, the solution of which is directly related to the development of social work and the professional training of competent specialists.
\end{abstract}

The purpose of the paper is to rationalize the possibility of improving professional training on the basis of the subjectactivity and contextual approaches. These approaches allow ensuring the formation of qualitative characteristics of a specialist adequate to the current conditions of professional activity.

As the research methods, the following methods were used: a content analysis, a questionnaire survey of 234 respondents.

The self-evaluation of their professional knowledge and skills is characterized and the readiness of social workers for training is analyzed. The possibility of improving vocational education on the basis of their educational needs is argued.

Taking into account professional difficulties and educational needs of social workers, educational and methodological guideline was developed and implemented, including teaching and methodological aids, and tasks that contribute to the formation of general cultural and professional competencies among future social workers and specialists already working in social protection organizations.

Keywords - social worker, educational needs, professional difficulties, readiness to professional activities, subject-activity approach, contextual approach.

\section{INTRODUCTION}

The formation of the system of social services for the population, the existence and emergence of new types of social protection institutions, that provide various social services, are the most important guarantees for improving the quality of life of various categories of people.

It is obvious that those who work in these institutions must have the appropriate education, skills and practices to provide social assistance, communicate with people and act according to professional and ethical standards.

The professionalism of a social worker is manifested in the continuous maintenance of high-level academic knowledge, skills to work with people and play many roles.

The purpose of the paper is to substantiate the possibility of improving professional training on the basis of the subject-activity and contextual approaches and characterizing the educational and methodological guideline for the vocational training of social workers.

Tasks:

1. To identify the professional difficulties of social workers;

2. To study the educational needs and the social workers' level of mastering professional knowledge and skills;

3. To study the opinions of employers on the level of professional readiness of bachelors and masters for professional work;

4. To describe the content of educational and methodological guideline for vocational training of social workers.

The analysis of the literature testifies that the problem of professional education is based on a wide range of academic developments by scholars in the field of education: the issues connected with the prospects of research in the field of social work are disclosed [1]; readiness for professional activity [2;3] and its evaluation [4] are studied. The analysis of professional values [5] and professional skills of social workers is presented $[6 ; 7]$

\section{MATERIALS AND METHODS}

To identify the educational needs and professional expectations and to study the level of proficiency and skills, a survey of 234 respondents was conducted [8]: employers (heads of social service organizations), students of the faculty of retraining and vocational training of the Kemerovo State University (future social workers and specialists working in social protection organizations). As the methods of research, a questionnaire survey and a content analysis of the specialists' professional standards in the social sphere were used.

\section{RESULTS AND DISCUSSION}

The analysis of the questionnaires made it possible to conclude that at the time of the survey, about $50 \%$ of social workers did not have any training for seven or more years. Only $1 \%$ of respondents have the education in the "Social Work" speciality. The rest came to the system of social protection of the population from the sphere of education, services, industries, or having an only basic general education.

The factors that influenced the choice and change of profession, as shown by the results of the study, are diverse. 
First of all, for the majority of respondents (77\%) this was the only opportunity to find a job in the current economic situation. For $61.5 \%$ of respondents, the fact that the job gives an opportunity to get satisfaction from the results of work was of great importance when choosing a profession. Many people, in the choice of profession, take into account the possibility of communicating with a wide range of people $(54 \%)$, the opportunity to use professional knowledge and skills outside work (38\%), to realize oneself (69\%), to move up the career ladder (53\%). But at the same time, respondents note that the profession of a social worker is not prestigious enough (31\%). Work in social protection organizations, according to respondents, does not contribute to professional development (45\%) and personal growth $(54 \%)$. And these reasons may have an effect on job satisfaction.

The next stage of this study was the study of selfassessment of the availability of necessary professional knowledge and skills. The presented list of professional knowledge and skills was compiled taking into account 2 separate professional standards and job responsibilities of the specialists in social work and actual social workers.

The results of the distribution of the professional knowledge level among respondents are presented in Table 1.

TABLE I. THE LEVEL OF EXPRESSING PROFESSIONAL KNOWLEDGE AMONG WORKERS OF SOCIAL SERVICE ORGANIZATIONS

\begin{tabular}{|c|c|c|c|}
\hline \multicolumn{3}{|c|}{$\begin{array}{l}\text { Level of expressing professional } \\
\text { knowledge }\end{array}$} & \multirow[t]{2}{*}{ Professional knowledge } \\
\hline $\begin{array}{l}(1) \\
\text { Low }\end{array}$ & $\begin{array}{c}\text { (2) } \\
\text { Average }\end{array}$ & $\begin{array}{c}(3) \\
\text { High } \\
\end{array}$ & \\
\hline $5(38 \%)$ & $8(61.5 \%)$ & $1(8 \%)$ & $\begin{array}{l}\text { 1. Knowledge of the content } \\
\text { and features of conducting } \\
\text { social forecasting and designing } \\
\text { in social work }\end{array}$ \\
\hline $5(38 \%)$ & $8(61.5 \%)$ & $1(8 \%)$ & $\begin{array}{l}\text { 2. Knowledge of the object } \\
\text { and the subject, the patterns, the } \\
\text { basic models of social } \\
\text { diagnostics in social work }\end{array}$ \\
\hline $3(23 \%)$ & $8(61.5 \%)$ & $3(23 \%)$ & $\begin{array}{l}\text { 3. Knowledge of the essence } \\
\text { and basic principles of state } \\
\text { social policy }\end{array}$ \\
\hline $4(31 \%)$ & $7(54 \%)$ & $3(23 \%)$ & $\begin{array}{l}\text { 4. Knowledge of the main } \\
\text { directions, functions, the } \\
\text { structure of social services }\end{array}$ \\
\hline $2(15 \%)$ & $6(46 \%)$ & $6(46 \%)$ & $\begin{array}{l}\text { 5. Knowledge of social policy } \\
\text { regarding the family, the elderly } \\
\text { and the disabled }\end{array}$ \\
\hline $1(8 \%)$ & $8(61,5 \%)$ & $5(38 \%)$ & $\begin{array}{l}\text { 6. Knowledge of the } \\
\text { regulations, rules, the directions, } \\
\text { goals and the content of social } \\
\text { work in organizations }\end{array}$ \\
\hline $4(31 \%)$ & $8(61,5 \%)$ & $2(15 \%)$ & $\begin{array}{l}\text { 7. Knowledge of the content, } \\
\text { forms and methods of } \\
\text { organization and management } \\
\text { in social work }\end{array}$ \\
\hline $4(31 \%)$ & $7(54 \%)$ & $3(23 \%)$ & $\begin{array}{l}\text { 8. Knowledge of providing } \\
\text { social and medical assistance }\end{array}$ \\
\hline $1(8 \%)$ & $12(92 \%)$ & $1(8 \%)$ & $\begin{array}{l}\text { 9. Knowledge of the basic } \\
\text { concepts, forms and methods of } \\
\text { consulting in social work }\end{array}$ \\
\hline $4(31 \%)$ & $8(61.5 \%)$ & $2(15 \%)$ & $\begin{array}{l}\text { 10. Knowledge of the features } \\
\text { of communication in social } \\
\text { work, related requirements, } \\
\text { establishing relationships with } \\
\text { all participants in the assistance } \\
\text { process }\end{array}$ \\
\hline 0 & $8(61.5 \%)$ & $6(46 \%)$ & $\begin{array}{l}\text { 11. Knowledge of solving } \\
\text { professional problems }\end{array}$ \\
\hline
\end{tabular}

\begin{tabular}{|c|c|c|c|}
\hline \multicolumn{3}{|c|}{$\begin{array}{l}\text { Level of expressing professional } \\
\text { knowledge }\end{array}$} & \multirow{2}{*}{$\begin{array}{l}\text { Professional knowledge } \\
\text { 12. Knowledge } \\
\text { psychological, social, medical } \\
\text { characteristics of the individual } \\
\text { and various groups of the } \\
\text { population receiving social } \\
\text { services }\end{array}$} \\
\hline $2(15 \%)$ & $10(77 \%)$ & $2(15 \%)$ & \\
\hline $1(8 \%)$ & $6(46 \%)$ & $7(54 \%)$ & $\begin{array}{l}\text { 13. Knowledge of regulations } \\
\text { (acts) in the field of social } \\
\text { protection of the population, } \\
\text { social services }\end{array}$ \\
\hline $4(31 \%)$ & $7(54 \%)$ & $3(23 \%)$ & $\begin{array}{l}\text { 14. Knowledge of the specifics } \\
\text { of social problems and the } \\
\text { needs of different groups of the } \\
\text { population }\end{array}$ \\
\hline $3(23 \%)$ & $6(46 \%)$ & $5(38 \%)$ & $\begin{array}{l}\text { 15. Knowledge of the } \\
\text { theoretical basis of social work: } \\
\text { basic concepts, principles, } \\
\text { patterns, methods of social work }\end{array}$ \\
\hline $2(15 \%)$ & $9(69 \%)$ & $3(23 \%)$ & $\begin{array}{l}\text { 16. Knowledge of the } \\
\text { professional roles of the social } \\
\text { worker, the requirements for } \\
\text { them and the functions } \\
\text { corresponding to these roles }\end{array}$ \\
\hline $1(8 \%)$ & $8(61.5 \%)$ & $5(38 \%)$ & $\begin{array}{l}\text { 17. Knowledge of qualification } \\
\text { requirements, job } \\
\text { responsibilities, requirements } \\
\text { for the positions of social } \\
\text { workers }\end{array}$ \\
\hline $2(15 \%)$ & $9(69 \%)$ & $3(23 \%)$ & $\begin{array}{l}\text { 18. Knowledge of the essence } \\
\text { of the contents, tools, methods } \\
\text { of the technology of social work } \\
\text { in various spheres of life and } \\
\text { with different categories of the } \\
\text { population }\end{array}$ \\
\hline $2(15 \%)$ & $9(69 \%)$ & $2(15 \%)$ & $\begin{array}{l}\text { 19. Knowledge of professional } \\
\text { and ethical norms (principles) of } \\
\text { professional activity }\end{array}$ \\
\hline $4(31 \%)$ & $8(61.5 \%)$ & $1(8 \%)$ & $\begin{array}{l}\text { 20. Knowledge of the economic } \\
\text { basis of social work }\end{array}$ \\
\hline $4(31 \%)$ & $7(54 \%)$ & $2(15 \%)$ & $\begin{array}{l}\text { 21. Knowledge of methods of } \\
\text { social and pedagogical work in } \\
\text { social institutions }\end{array}$ \\
\hline $7(54 \%)$ & $6(46 \%)$ & $1(8 \%)$ & $\begin{array}{l}\text { 22. Knowledge of methods of } \\
\text { correction work }\end{array}$ \\
\hline $2(15 \%)$ & $10(77 \%)$ & $2(15 \%)$ & $\begin{array}{l}\text { 23. Knowledge of methods of } \\
\text { conducting rehabilitation work }\end{array}$ \\
\hline $3(23 \%)$ & $11(85 \%)$ & 0 & $\begin{array}{l}\text { 24. Knowledge of medical and } \\
\text { social basics in social work, } \\
\text { knowledge of human } \\
\text { physiology }\end{array}$ \\
\hline $1(8 \%)$ & $3(23 \%)$ & $10(77 \%)$ & $\begin{array}{l}\text { 25. Knowledge of the features } \\
\text { of the workplace (working } \\
\text { conditions, facilities, working } \\
\text { schedule, HSE requirements) }\end{array}$ \\
\hline
\end{tabular}

Carefully analyzing the answers, it is possible to distinguish the educational needs of social workers: they are experiencing a need for knowledge and skills in conducting social forecasting and designing, developing social programs. They need to improve their communication skills, as well as the skills in providing socio-medical, sociopsychological and social-pedagogical services; noting a lack of knowledge and skills in academic and methodological support of social services, a lack of managerial skills.

Managerial skills play a special, systematizing role in the activities of a specialist, no matter what position he or she is working at. Therefore, the achievement of a high level of managerial culture is not only a basis for the further professional development of a specialist but an indispensable condition for the development of the entire social service system. 
Managerial competence of a specialist assumes a certain level of managerial experience, the existence of a system of beliefs and value orientations, and the possession of methods of managerial activity. The tasks of this research were to identify the most and least significant managerial competencies, according to employers, and to study the employers' opinions on the level of graduates' professional readiness.

To determine the managerial competencies, a content analysis of the professional standards of specialists in the social sphere was used. As a result, the questionnaire developed for employers included 20 competencies, the significance of which was to be assessed on a ten-point scale:

- $\quad$ ability to apply knowledge in practice;

- teamwork;

- leadership ability;

- $\quad$ ability to improve the quality of service;

- ability to do consulting and preventive work in the social sphere;

- $\quad$ ability to establish business contacts with specialists from different services and organizations;

- willingness to demonstrate a humanistic approach to people;

- $\quad$ ability to purposefully and effectively implement modern technologies of social work;

- computer skills;

- $\quad$ ability to organize and plan;

- ability to develop social projects to implement various areas of social policy;

- readiness for effective communication when organizing work on the social protection of the population;

- $\quad$ ability to prevent professional burnout;

- ability to oral statements;

- $\quad$ ability to perform work full of diversity;

- $\quad$ ability to win the trust of clients and colleagues;

- ability to resolve conflicts and mitigate disagreement;

- $\quad$ readiness to be engaged in organizational and social planning;

- reliability and responsibility, adequate response to socio-economic changes in the society;

- $\quad$ ability to generate new ideas (creativity).

The obtained results concerning students' possession of management competencies are shown in Figure 1.

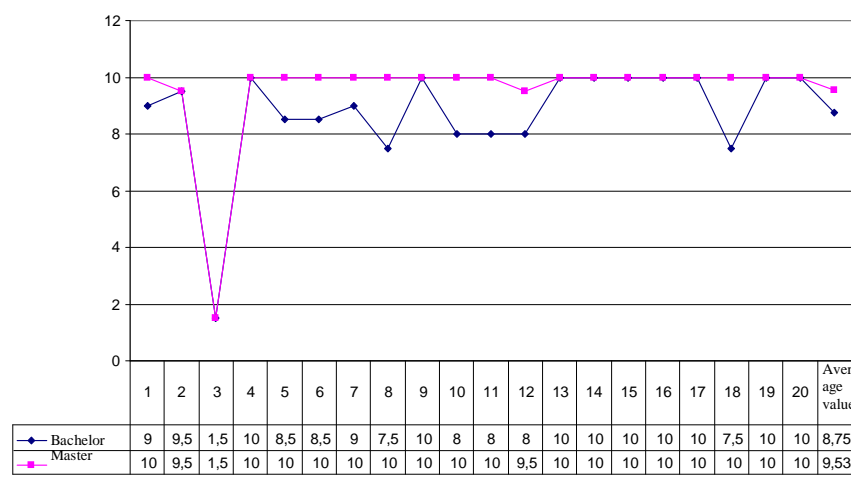

Fig. 1. Evaluation of the managerial competencies of bachelors and masters by employers

As a result of the survey of employers, the most significant managerial competencies of bachelors and masters were identified:

- $\quad$ ability to improve the quality of service;

- computer skills;

- $\quad$ ability to prevent professional burnout;

- ability to resolve conflicts and mitigate discrepancies;

- $\quad$ reliability and responsibility;

- $\quad$ ability to generate new ideas (creativity).

Shkaratan adheres to this point of view [9, p. 31-39], highlighting the list of qualities that an employee needs to implement effective management solutions:

- readiness for continuous innovation;

- preparedness for processing and evaluating information;

- ability to navigate in extreme situations, make nonstandard decisions, analyze emerging problems;

- readiness to combine personal and group interests, establish contacts within the group;

- initiative, business acumen;

- inclusion in the system of continuing education;

- professional, qualification, territorial mobility.

From the above graph, it can be seen that the average score for assessing the knowledge level of a master (9.53) is higher than that of a bachelor (8.75). In this regard, one can reasonably conclude that, according to the employers, the level of professional training of a master is higher than that of a bachelor. The masters, in contrast to the bachelors, in addition to these competencies, also received the highest score in such competencies as:

- ability to apply knowledge in practice;

- ability to do consulting and preventive work in the social sphere;

- $\quad$ ability to establish business contacts with specialists of different services and organizations;

- readiness to demonstrate a humanistic approach to people; 
- $\quad$ ability to purposefully and effectively implement modern technologies of social work;

- $\quad$ ability to organize and plan;

- ability to develop social projects to implement various areas of social policy;

- $\quad$ ability to be responsible;

- adequate response to socio-economic changes in society.

Consequently, in the opinion of employers, a master must manage practically all the proposed competencies in perfection, although a bachelor's degree is also quite high in the following competencies:

- $\quad$ ability to apply knowledge in practice - 9 points;

- ability to do consulting and preventive work in the social sphere -8.5 points;

- $\quad$ ability to establish business contacts with specialists of different services and organizations -8.5 points;

- readiness to demonstrate a humanistic approach to people -9 points.

It should also be noted that such competence as the ability to become a leader is assessed very low -1.3 points, both for masters and for bachelors.

Thus, one can talk about the contradiction that has developed at the present time. The processes of modernization of the social sphere require specialists to perform functions that they are not ready to fulfil due to the lack of practical skills and experience, but rather little theoretical preparation. As a consequence, the insufficient professionalism of specialists directly affects the operational effectiveness of the entire institution. The situation can be solved by improving the skills of specialists in social service organizations for the population.

The results of the research show that the need for professional development is conditioned by: 1) the lack of professional education among specialists; 2) expansion of the types of activity of social workers (work with the elderly, problem children, in the education system, in the penitentiary system, etc.); 3) development of theory and practice of social work and social pedagogy; 4) opportunity to study and adopt the foreign experience of social work.

The main purpose of training is to create in the course of professional vocational training the conditions for the acquisition of new professional human opportunities based on education and work experience available.

The study of the opinions of employers, professional difficulties and educational needs of practising social workers makes it possible to improve the process of professional training of students.

In pedagogical theory and practice, a sufficient number of approaches to the organization of the educational process have been developed. The subject-activity and contextual approaches will ensure both the improvement of vocational training of students and upgrading the skills of social workers. The subject-activity approach enables to emphasize the importance of continuous professional and personal development, to form the professional competence of experts in accordance with professional assignments via accumulation in the transition to the next educational level of qualities, abilities, skills, compliant with the professional standards, leading to a qualitative change in their development $[10 ; 11 ; 12]$.

Intensively used in recent times, the contextual approach significantly changes the emphasis in the field of professional training of specialists. The contextual approach in the system of vocational education contributes to the professional and social training of specialists since it involves the implementation of the learning process in the context of future professional activities.

In many studies, domestic and foreign scientists $[13 ; 14$; $15 ; 16 ; 17 ; 18]$ refer to the successful results of contextual learning. The main idea of contextual learning is modelling in the forms of students' academic activities of real production links and relationships. It enables to bridge the gap between professional training and real production activities.

On the basis of these approaches, educational and methodological support was developed and implemented in the educational process of the Socio-psychological Institute of the Kemerovo State University $[10 ; 11 ; 12 ; 19]$. The teaching and methodological guideline is a combination of tools that contribute to the formation of professional competence of the future social workers. The tools of educational and methodological support are the teaching and methodological program, working programs and teaching materials for particular disciplines. With the help of the proposed training and methodological support, including technological maps, textbooks on disciplines, a program developed for organizing students' work experience and educational and methodological recommendations for conducting seminars (content and recommendations for business and role games, situation analysis, development of social projects, characteristics of teaching methods), it is possible to improve the organization of the process of mastering theoretical knowledge and the formation of professional skills. Educational and methodological support is aimed at interiorization by students of cultural and environmental external factors of self-development into personal, improvement of the interaction of the parties to the educational process of the university with the external social environment (students, teachers, heads of practices).

Case studies, one of the options for modelling future professional activity, are the part of the teaching and methodological guideline. The situation is a combination of facts and data that determine a particular phenomenon. The merits of this method include the possibility of active participation of students in decision-making, openly expressing their opinions on various ways of solving various problems, developing skills to establish business and professional contacts, making collective decisions, and eliminating conflicts, which will help to shape the competencies of the future specialists $[7 ; 20 ; 21 ; 22 ; 23 ; 24]$.

The "Method of correspondence" and case studies are applied in studying such a discipline as "Legal provision of social work". The ability to analyze regulations, to correlate the norms of various legal sources are formed when solving practical and theoretical problems. The purpose of the " method of correspondence" is to develop the skills of a systemic vision of a problem or a situation: on the basis of disparate information reflected in different documents, 
trainees should compile an integrated view of a situation or a problem.

\section{CONCLUSION}

The task of raising the level of skills of social workers is to help students competently integrate knowledge, values and skills of the profession in their practical activities.

Proceeding from the multifunctionality of the professional activity of social workers, it is important to pay attention to the implementation of educational and methodological guidelines, which is understood as the professional activity of the teacher, aimed at creating social and pedagogical conditions for the successful training and personal development of specialists that promote good quality implementation of educational programs in accordance with the requirements of federal state educational standards, professional standards, labour market, educational difficulties, needs, and typical tasks of professional activity.

\section{REFERENCES}

[1] L. Lein, E.S. Uehara, E. Lightfoot, and E.F. Lawlor, “A collaborative framework for envisioning the future of social work research and Education," in Social Work Research, vol. 41, issue 2, pp. 67-71, 2017.

[2] Q. An, and M.V. Chapman, "The early professional experience of a new social worker in China," in Journal of Social Work Education, issue 50(2), pp.322-333, 2014.

[3] S. Grant, L. Sheridan, and A.S. Webb, "Newly qualified socia workers' readiness for practice in Scotland," in The British Journal of Social Work, vol. 47, issue 2, pp. 487-506, 2017.

[4] J.W. Drisko, "Competencies and their assessment," in Journal of Social Work Education. issue 50(3), pp. 414-426, 2014.

[5] E. Tartakovsky, and D.S. Walsh, "Value preferences of social workers," in Social Work, vol. 63, issue 2, pp. 115-124, 2018

[6] G. Karpetis, "Social work skills: a narrative review of the literature," in The British Journal of Social Work, vol. 48, issue 3, pp. 596-615, 2018

[7] G. Dykes, and S. Green, "Learning profiles of social work students: who are you and how should this influence my teaching?" in Social Work South Africa, issue 51(4), pp. 577-598, 2015.

[8] D.V. Svoboda, C.D. Williams, A.L. Jones, and K.H. Powell, "Teaching social work research through practicum: What the students learned," in Journal of Social Work Education, issue 49(4), pp.661673, 2013.

[9] O.I. Shkaratan, "The Russian culture of labour and management," in Social Sciences and Modernity, vol.1, pp. 30-54, 2003.

[10] "Global standards for the education and training of the social work profession," Adelaide: Australia, 2004, 24 p. URL: http://ifsw.org/policies/global-standards.

[11] R. Greene, "Roles and functions of nursing home social workers in the provision of psychosocial care," Washington: DC, 2004, $211 \mathrm{p}$.

[12] "Social work services in nursing homes: Toward quality psychosocial care". URL: http://www.socialworkers.org/practice/standards/nursing homes.asp.

[13] J. A Bouchard, "Proposal for Reforming Psychologists [Training in France and in the European Union]," in Encephale, vol. 35, no. 1, 2009, pp. 18-24, doi:10.1016/j.encep.2007.11.008.

[14] M..Krumer-Nevo, "Poverty and the political: wresting the political out of and into social work theory, research and practice," in European Journal of Social Work, vol. 20, no. 6, pp. 811-822, 2017.

[15] A. Westhues, C. Barsen, N. Freymond, and P. Train, "An outcome evaluation of a problem-based learning approach with MSW students," in Journal of Social Work Education, issue 50(3), pp.472489, 2014.

[16] L.I. Antsyferova, "Psychological content of the phenomenon of the subject and the boundaries of the subject-activity approach," in Problems of the subject in psychological science, Moscow: AcademProect, pp. 27-42, 2000. (in Russian)
[17] E.V. Filatova, "Subject-activity approach as the basis of professional training of social workers," in Azimuth of scientific research: pedagogy and psychology, vol. 5, issue 4(17), pp. 276-280, 2016.

[18] A.A. Verbitsky, and O.G. Larionova, "Personality and competence in education. Problems of integration,” Moscow: Logos, 2009, 336 p. (in Russian).

[19] E.F. Zeer, "Key Qualifications and Competencies in Personally Oriented Professional Education," in Education and Science, vol. 3, pp. 90-120, 2000.

[20] I.A. Zimnyaya, "Key competencies - a new paradigm of the result of education," in Higher education today, vol. 5, pp. 34-32, 2003.

[21] A.V. Khutorsky, "Determination of the general content and key competencies as a characteristic of a new approach to the design of educational standards," in Competencies in Education: Collection of scientific works, Moscow: Scientific and innovative enterprise "INEC", 327 p., 2007. (in Russian).

[22] M.E. Bershadsky, and V.V. Guzeev, "Didactic and psychological foundations of educational technology," Moscow: Center "Pedagogical Search", 2003, 256 p. (in Russian).

[23] V.A. Bolotov, and V.V. Serikov, "Competence model: from idea to an educational program," in Pedagogics, vol. 10, pp. 8-14, 2003.

[24] J. Raven, "Competence in modern society: identification, development and implementation," Moscow, 2002, 396 p. (in Russian). 